\title{
Groundwater Recharge Area Based on Hydrochemical and Environmental Isotopes Analysis in the South Bandung Volcanic Area
}

\author{
Rizka Maria $^{1,2^{\star}}$, Satrio ${ }^{1,3}$, Teuku Yan Waliyana Muda Iskandarsyah ${ }^{1}$, Bombom Rachmat Suganda $^{1}$, \\ Robert Mohammad Delinom², Dyah Marganingrum², Wahyu Purwoko², \\ Dady Sukmayadi ${ }^{2}$, and Hendarmawan Hendarmawan ${ }^{1}$
}

${ }^{1}$ Faculty of Geological Engineering, Padjadjaran University, Jl. Raya Bandung Sumedang Km 21, Jatinangor, Sumedang 45363, Indonesia

${ }^{2}$ Research Center for Geotechnology LIPI, Jl. Sangkuriang, Bandung 40135, Indonesia

${ }^{3}$ Center for Isotopes and Radiation Application - BATAN, Jl. Lebak Bulus Raya No. 49, Jakarta 12440, Indonesia

* Corresponding author:

tel: $+62-81321409165$

email:rizka_maria@yahoo.com

Received: August 14, 2020

Accepted: November 20, 2020

DOI: $10.22146 /$ ijc. 58633

\begin{abstract}
The determination of recharge areas needs to support the groundwater conservation in the southern volcanic Bandung area. This study aims to determine the recharge area based on environmental isotopes and hydrochemical. A sampling of 26 groundwater was carried out at springs, dug wells, and drilling wells. The variation in groundwater chemistry principally is controlled by a combination of ion exchange, silicate weathering, calcite, and dolomite dissolution of minerals. The hydrochemical facies were $\mathrm{CaCl}, \mathrm{CaMgCl}, \mathrm{CaMgHCO}, \mathrm{CaHCO}_{3}$, and $\mathrm{NaKHCO}_{3}$. The $\mathrm{CaHCO}_{3}$ facies describe moderate groundwater flows. The $\mathrm{NaKHCO}_{3}$ facies shows the mixing of shallow and deep groundwater. The recharge area in the central, proximal, and medial facies zone consists of 3 groups. Group I is considered water originating from local rainwater infiltration; Group II is considered the infiltration elevation, which ranges from 980-1230 m asl; Group III estimated to be derived from the recharge elevation between 750-970 $\mathrm{m}$ asl, Group IV are more likely to show symptoms of evaporation or interaction with surface water. The discharge area is characterized by less active groundwater circulation, with dominant $\mathrm{HCO}_{3}{ }^{-}$and TDS values in the distal facies zone. Hydrochemical variation helped the identification of recharge areas in the volcanic facies.
\end{abstract}

Keywords: volcanic facies; recharge; groundwater; environmental isotopes

\section{- INTRODUCTION}

A volcanic area is a place for groundwater recharge and water resources for the surrounding community [1]. The need for groundwater is increasing along with the development and population growth [2]. Excessive groundwater extraction will cause environmental changes such as reduced groundwater reserves, drought in the dry season, and groundwater pollutants. Groundwater recharge is influenced by environmental changes and anthropogenic conditions [3-4]. The South Bandung volcanic area is part of the upstream Citarum watershed located in Bandung Regency. The potential of abundant water resources in this area is the main buffer for the fulfillment of raw water for Bandung Municipality and Bandung Regency [5]. Expansion of built land for settlements in the South Bandung area is feared to affect the groundwater conservation area [6]. There has been a deficit of groundwater in South Bandung in 2015, amounting to $170,215,063 \mathrm{~m}^{3} /$ year [5]. The large potential of water sources must be preserved.

One of the methods used to validate hydrogeological conditions is an environmental isotope and hydrochemical analysis [1-2,4,7-9]. Isotope composition in hydrological systems in nature are influenced by physical variables, namely air temperature, air pressure, humidity, geographical 
location, and altitude [10]. The reaction between groundwater and minerals in aquifers affects groundwater quality, such as cation and anion exchange reactions [8]. Groundwater genesis can be seen from the composition of groundwater, and the processes occur when passing through aquifer media [9]. Research on hydrochemical and stable isotopes in hydrogeological systems at Bandung-Soreang and Batujajar Groundwater Basin has been widely carried out by several researchers [6,11-17]. Previous isotope research for groundwater recharge in the Bandung Basin has been carried out based on groundwater type. Even though in one kind of groundwater, it does not necessarily indicate groundwater system the same. The differences with the previous studies, in this study, the groundwater recharge was determined based on the isotope value and hydrochemical volcanic facies analysis. The study aimed to identify recharge areas with stable isotope and hydrochemical analysis of volcanic facies. Environmental isotopes used are the stable isotope deuterium $\left(\delta^{2} \mathrm{H}\right.$ or $\left.\mathrm{D}\right)$ and oxygen-18 $\left(\delta^{18} \mathrm{O}\right)$. The stable isotopes Deuterium and oxygen-18 are also used to determine the origin of groundwater.

\section{- EXPERIMENTAL SECTION}

\section{Location and Sampling}

The research was conducted in the South Bandung volcanic area, geographically located at $107^{\circ} 30^{\prime} \mathrm{E}-$ $107^{\circ} 45^{\prime} \mathrm{E}$ and $7^{\circ} 00^{\prime} \mathrm{S}-7^{\circ} 10^{\prime} \mathrm{S}$ (Fig. 1). The southern part of the Bandung Basin is surrounded by Malabar Wayang Windu Patuha volcanoes [18]. The geological condition from the study area consists of: The Beser Formation $(\mathrm{Tmb})$ is the oldest rock in the late Miocene, consist of tuffaceous breccias, lava, andesite and basalt. Quaternary



Fig 1. Research location on geological map [27-28] 
volcanic rocks overlay Tertiary volcanic rocks. Old unraveled volcanic deposits (Qopu) of Pleistocene age, consisting of fine-coarse crystalline tuff, dacite, tuff breccia containing old pumice and andesite lava deposits. The youngest rock unit is lake deposits (Qd) of the Holocene age. The distribution of springs is located in the old volcanic deposits (Qopu) and the Malabar volcanic deposits (Qmt) [19-20].

Volcanic facies have characteristics based on the geological condition, sedimentary structures, and biological conditions [18]. The study area's volcanic facies consist of the central, proximal, medial, and distal facies. The central facies are located in the Pangalengan area, the proximal facies on the upper slopes of Mount Malabar, the medial facies on the lower slopes, and the distal facies plain area of the lake deposits.

\section{Instrumentation}

Retrieval of 26 groundwater samples consist of 5 dug wells, 13 drillings wells, and 8 springs were taken during the rainy season. Field parameters such as $\mathrm{pH}$, electrical conductivity, and temperature were measured at each site using Horiba measuring instruments. Water samples from dug wells are taken from the top, middle, and bottom of the well to maintain homogeneity using a vertical water sampler made of $600 \mathrm{~mL}$ volume glass fiber. The water samples are put into a $500 \mathrm{~mL}$ polyethylene bottle and preserved. The process of taking stable isotope $\delta^{2} \mathrm{H}$ and $\delta^{18} \mathrm{O}$ samples is by taking water samples in $100 \mathrm{~mL}$ polyethylene bottles tightly closed to prevent evaporation. Stable isotope analysis was performed on the hydrogeochemistry laboratory of Institute Technology Bandung. The values of $\delta^{2} \mathrm{H}$ and $\delta^{18} \mathrm{O}$ were measured relative to the Vienna Standard Mean Ocean Water (VSMOW) using the Picaro L-2130-i Analyzer. The allowable error in the analysis is $\pm 0.2 \%$ for $\delta^{18} \mathrm{O}$ or $\pm 1.0 \%$ for $\delta^{2} \mathrm{H}$. The local meteoric water line (LMWL) equation is determined by considering a weighted total factor, namely the monthly rainfall at each rainwater sampling location [21].

\section{Procedure}

\section{Major ion analysis}

Laboratory analysis was carried out for the Total
Dissolve Solid (TDS) and major ions: $\mathrm{Ca}^{2+}, \mathrm{Mg}^{2+}, \mathrm{Na}^{+}$, $\mathrm{K}^{+}, \mathrm{SO}_{4}{ }^{2-}, \mathrm{Cl}^{-}, \mathrm{HCO}_{3}$. The analysis was carried out in the groundwater laboratory of the Research Center for Geotechnology LIPI. The $\mathrm{Na}^{+}, \mathrm{K}^{+}$were analyzed by atomic absorption spectrophotometry methods. The $\mathrm{HCO}_{3}{ }^{-}$was carried out by acidimetric methods. The $\mathrm{SO}_{4}{ }^{2-}$ was investigated by turbidimetry methods. The $\mathrm{Cl}^{-}$ was carried out using argentometry methods. Gravimetry methods determined TDS analysis. The concentrations of $\mathrm{Ca}^{2+}$ and $\mathrm{Mg}^{2+}$ were analyzed by complexometric titration with EDTA. A hydrochemical analysis is validated with ion balance. The quality of laboratory analysis results can be seen from the charge balance error (CBE), with the formula [22]:

$\mathrm{BE}=\frac{\sum \mathrm{Zm}_{\mathrm{c}}-\sum \mathrm{Zm}_{\mathrm{a}}}{\sum \mathrm{Zm}_{\mathrm{c}}+\sum \mathrm{Zm}_{\mathrm{a}}} \times 100$

$\mathrm{Z}$ notation is ion valence, $\mathrm{m}_{\mathrm{c}}$ is the molality of cation, and $\mathrm{m}_{\mathrm{a}}$ is the anion's molality.

CBE values can be accepted if $<5 \%$ [22]. Laboratory analysis results are presented using graphical methods, bivariate analysis, and correlation statistics. The combination of graphical and statistical analysis will produce an accurate classification that supports the accuracy of research results [23]. This result can be used as a groundwater facies indicator.

\section{Correlation analysis}

The correlation coefficient uses the Spearman method to determine the relationship between several hydrochemical parameters [24]. The correlation values $(\mathrm{r})>0.7$ indicating strong correlation, between $0.5-0.7$ indicating moderate correlation, and $<0.3$ indicating weak correlation [24]. The closeness of the relationship between variables was analyzed using the Spearman method processed with Minitab.19 software.

\section{Hydrogeochemical analysis}

A hydrogeochemical analysis is one of the techniques used to study groundwater quality [24]. Piper diagram analysis was carried out to show groundwater's evolution and the relationship between various dissolved ions from geochemical data analysis [25]. One of the groundwater facies type determinants is the dissolving of plagioclase, ferromagnesian minerals, 
carbonates, and cation exchange process [26]. Groundwater with a predominance of bicarbonate $\left(\mathrm{HCO}_{3}{ }^{-}\right)$concentrations comes from shallow and young groundwater. The main source of $\mathrm{HCO}_{3}{ }^{-}$is $\mathrm{CO}_{2}$ dissolved in rainwater and infiltrated into the soil [9].

\section{Isotope analysis}

Determination of the recharge area elevation from isotope can be performed using natural isotope methods, namely $\delta^{2} \mathrm{H}$ and $\delta^{18} \mathrm{O}$ isotope in water molecules [2,21]. Water-rock interactions, evaporation, mixing, water origin, and accompanying processes are known by comparing the isotopic composition of water with reference $[3,16]$. The altitude effect and the amount of rainfall can be used to find the relationship between the isotope composition of rainwater and the altitude of a recharge area [27]. Determination of groundwater origin was carried out using the ratio of heavy isotopes to light isotopes, which were determined in terms of the difference in the rate of $\delta^{2} \mathrm{H}$ and $\delta^{18} \mathrm{O}$ isotopes. The isotope ratio $\delta^{2} \mathrm{H}$ and ${ }^{18} \mathrm{O}$ will experience fractionation when there is a physical change in water molecules due to differences in isotopic mass in the hydrological cycle [27]. Rainwater falls at different elevations will have different isotope ratios where the higher the height of a place will be depleted the isotope composition [28].
The analysis of the $\delta^{18} \mathrm{O}$ and $\delta^{2} \mathrm{H}$ isotope composition of the water samples was performed using the Picaro L-2130-i Instrument. The abundance of $\delta^{2} \mathrm{H}$ and $\delta^{18} \mathrm{O}$ molecules in water is not measured in absolute ratio but in terms of their relative abundance to a standard. The relative abundance of the $\mathrm{HD}^{16} \mathrm{O}$ molecule is called the relative abundance of deuterium $\left(\delta^{2} \mathrm{H}\right)$, and the close lot of $\mathrm{H}_{2}{ }^{18} \mathrm{O}$ is called the $\delta \mathrm{O}^{18}$. The relative mass of $\delta^{18} \mathrm{O}$ and $\delta^{2} \mathrm{H}$ in water molecules is measured relative to an international standard SMOW (Standard Mean Ocean Water). The relative lot of ${ }^{2} \mathrm{H}$ is written as $\delta^{2} \mathrm{H}$, with the formula:

$\delta=\frac{\mathrm{R}_{\text {Sample }}-\mathrm{R}_{\text {SMOW }}}{\mathrm{R}_{\text {SMOW }}} \times 1000 \%$

where, $\mathrm{R}_{\text {sample }}=$ the isotope ratio $\left(\delta^{2} \mathrm{H}\right.$ or $\left.\delta^{18} \mathrm{O}\right)$ of the sample, in $\%$; $\mathrm{R}_{\text {SMOW }}=$ the isotope ratio $\left(\delta^{2} \mathrm{H}\right.$ or $\left.\delta^{18} \mathrm{O}\right)$ of the SMOW

\section{- RESULTS AND DISCUSSION}

\section{Groundwater Hydrochemical Processes}

The summary of the physical and chemical properties is given in Table 1 and 2. The physicochemical properties from the field data collection and the chemical properties are taken from laboratory analysis.

Table 1. The summary of the physico-chemical properties in the research area

\begin{tabular}{|c|c|c|c|c|c|c|c|}
\hline $\begin{array}{l}\text { Type of } \\
\text { sample }\end{array}$ & $\mathrm{X}$ & Y & $\begin{array}{c}\text { Type of } \\
\text { groundwater }\end{array}$ & $\begin{array}{l}\text { Elevation } \\
(\mathrm{m})\end{array}$ & $\mathrm{pH}$ & Temp $\left({ }^{\circ} \mathrm{C}\right)$ & $\begin{array}{l}\text { Conductivity } \\
(\mu \mathrm{S} / \mathrm{cm})\end{array}$ \\
\hline Ma2 & 784217 & 9205750 & Spring & 1427 & 5.4 & 22.6 & 220 \\
\hline Sb9 & 784363 & 9217295 & Drilling well & 809 & 7.4 & 28.4 & 100 \\
\hline Sp11 & 776614 & 9221798 & Dug well & 816 & 6.9 & 25.3 & 370 \\
\hline Ma14 & 782672 & 9212796 & Spring & 915 & 7.1 & 25.5 & 160 \\
\hline Sg15 & 790418 & 9224231 & Dug well & 700 & 7.2 & 26.0 & 700 \\
\hline Sb16 & 790554 & 9223882 & Drilling well & 701 & 6.7 & 27.7 & 230 \\
\hline Ma17 & 790591 & 9223757 & Spring & 718 & 7.2 & 26.9 & 160 \\
\hline Ap18 & 790159 & 9223906 & Lake & 720 & 7.5 & 25.4 & 160 \\
\hline $\mathrm{Sb} 20$ & 793352 & 9222272 & Drilling well & 707 & 7.3 & 27.6 & 300 \\
\hline $\mathrm{Sb} 21$ & 793292 & 9222526 & Drilling well & 720 & 7.3 & 28.8 & 330 \\
\hline $\mathrm{Ma} 23$ & 797460 & 9220890 & Spring & 716 & 6.9 & 28.5 & 230 \\
\hline $\mathrm{Sb} 25$ & 797545 & 9217430 & Drilling well & 810 & 6.4 & 26.4 & 70 \\
\hline $\mathrm{Ma} 27$ & 794474 & 9219337 & Spring & 855 & 6.7 & 26.7 & 130 \\
\hline Sb35 & 781008 & 9221806 & Drilling well & 700 & 7,9 & 25.4 & 460 \\
\hline Sb37 & 779361 & 9222239 & Drilling well & 749 & 7,7 & 27.2 & 350 \\
\hline $\mathrm{Sb} 42$ & 781448 & 9223008 & Drilling well & 703 & 7.4 & 29.3 & 460 \\
\hline
\end{tabular}


Table 1. The summary of the physico-chemical properties in the research area (Continued)

\begin{tabular}{lcclcccc}
\hline $\begin{array}{c}\text { Type of } \\
\text { sample }\end{array}$ & $\mathrm{X}$ & $\mathrm{Y}$ & $\begin{array}{c}\text { Type of } \\
\text { groundwater }\end{array}$ & $\begin{array}{c}\text { Elevation } \\
(\mathrm{m})\end{array}$ & $\mathrm{pH}$ & Temp $\left({ }^{\circ} \mathrm{C}\right)$ & $\begin{array}{c}\text { Conductivity } \\
(\mu \mathrm{S} / \mathrm{cm})\end{array}$ \\
\hline Sb42 & 781448 & 9223008 & Drilling well & 703 & 7.4 & 29.3 & 460 \\
Sp44 & 783701 & 9223886 & Dug well & 692 & 7.4 & 29.8 & 390 \\
Sb45 & 788997 & 9227341 & Drilling well & 689 & 7.7 & 28.9 & 440 \\
Sb 49 & 777512 & 9221024 & Drilling well & 734 & 7.7 & 31.2 & 550 \\
Sb50 & 785689 & 9920350 & Drilling well & 706 & 7.7 & 28.7 & 230 \\
Sb52 & 786103 & 9221573 & Drilling well & 696 & 7.6 & 28.9 & 400 \\
Sp54 & 783759 & 9220403 & Dug well & 705 & 7.3 & 28.2 & 330 \\
Sg57 & 786348 & 9215868 & Dug well & 965 & 6.1 & 24.8 & 50 \\
Ma58 & 786522 & 9213881 & Spring & 1179 & 6.5 & 24.2 & 60 \\
Sb60 & 774648 & 9216127 & Drilling well & 1059 & 7.5 & 26.3 & 170 \\
Ma63 & 776683 & 9215129 & Spring & 1222 & 7.4 & 28.2 & 70 \\
\hline
\end{tabular}

Table 2. The summary of the major ion's chemical analysis in the research area

\begin{tabular}{|c|c|c|c|c|c|c|c|c|c|}
\hline $\begin{array}{l}\text { Type of } \\
\text { sample }\end{array}$ & $\begin{array}{l}\text { TDS } \\
(\mathrm{mg} / \mathrm{L})\end{array}$ & $\begin{array}{c}\mathrm{Na}^{+} \\
(\mathrm{mg} / \mathrm{L})\end{array}$ & $\begin{array}{c}\mathrm{K}^{+} \\
(\mathrm{mgL})\end{array}$ & $\begin{array}{c}\mathrm{Mg}^{2+} \\
(\mathrm{mg} / \mathrm{L})\end{array}$ & $\begin{array}{c}\mathrm{Ca}^{2+} \\
(\mathrm{mg} / \mathrm{L})\end{array}$ & $\begin{array}{c}\mathrm{Cl}^{-} \\
(\mathrm{mg} / \mathrm{L})\end{array}$ & $\begin{array}{c}\mathrm{SO}_{4}{ }^{2-} \\
(\mathrm{mg} / \mathrm{L})\end{array}$ & $\begin{array}{l}\mathrm{HCO}_{3}^{-} \\
(\mathrm{mg} / \mathrm{L})\end{array}$ & $\begin{array}{l}\text { CBE } \\
(\%)\end{array}$ \\
\hline Ma2 & 96 & 15.0 & 3.3 & 10.7 & 13.4 & 56.2 & 10.3 & 18.5 & 4.1 \\
\hline Sb9 & 126 & 10.1 & 5.0 & 3.9 & 7.7 & 6.9 & 6.4 & 63.2 & -3.4 \\
\hline Sp11 & 326 & 16.6 & 2.5 & 16.3 & 37.8 & 66.8 & 8.7 & 98.5 & 2.0 \\
\hline Ma14 & 114 & 14.2 & 4.7 & 4.9 & 14.6 & 9.6 & 6.7 & 81.7 & -1.3 \\
\hline Sg15 & 518 & 36.4 & 30.9 & 16.2 & 66.5 & 78.5 & 48.0 & 216.7 & -3.5 \\
\hline Sb16 & 244 & 15.0 & 1.5 & 4.4 & 28.4 & 20.7 & 9.8 & 97.5 & 1.7 \\
\hline Ma17 & 196 & 10.1 & 1.1 & 7.1 & 18.8 & 5.5 & 5.3 & 94.9 & -4.1 \\
\hline Ap18 & 160 & 11.7 & 1.4 & 6.1 & 17.3 & 12.4 & 11.0 & 73.8 & -3.4 \\
\hline Sb20 & 238 & 13.0 & 1.3 & 12.4 & 36.4 & 5.5 & 5.0 & 168.7 & -1.5 \\
\hline $\mathrm{Sb} 21$ & 206 & 14.6 & 1.7 & 17.4 & 35.3 & 13.8 & 5.1 & 176.6 & -3.7 \\
\hline $\mathrm{Ma} 23$ & 152 & 14.2 & 0.6 & 9.2 & 24.8 & 16.5 & 14.9 & 89.9 & 4.0 \\
\hline $\mathrm{Sb} 25$ & 28 & 7.7 & 0.6 & 1.2 & 5.8 & 9.4 & 8.2 & 22.3 & -3.9 \\
\hline Ma27 & 48 & 3.7 & 0.6 & 3.9 & 15.0 & 12.4 & 6.2 & 47.4 & -3.9 \\
\hline Sb35 & 376 & 42.4 & 3.3 & 7.4 & 20.9 & 22.0 & 5.7 & 139.4 & -3.5 \\
\hline Sb37 & 246 & 26.8 & 10.9 & 7.3 & 31.2 & 11.0 & 11.8 & 200.8 & -3.3 \\
\hline $\mathrm{Sb} 42$ & 186 & 27.6 & 8.6 & 18.1 & 29.8 & 13.8 & 4.8 & 258.3 & -3.6 \\
\hline Sp44 & 200 & 7.3 & 7.1 & 11.2 & 42.3 & 6.9 & 4.6 & 220.3 & -5.0 \\
\hline $\mathrm{Sb} 45$ & 280 & 25.4 & 6.2 & 16.6 & 36.1 & 16.5 & 4.7 & 228.3 & -4.2 \\
\hline $\mathrm{Sb} 49$ & 320 & 44.3 & 3.2 & 13.4 & 31.9 & 55.3 & 7.5 & 141.2 & -3.7 \\
\hline Sb50 & 172 & 25.4 & 3.4 & 6.1 & 15.1 & 20.7 & 4.9 & 103.3 & -3.7 \\
\hline Sb52 & 308 & 32.9 & 2.8 & 7.9 & 20.6 & 53.8 & 4.6 & 107.0 & -2.8 \\
\hline Sp54 & 252 & 20.8 & 2.5 & 21.1 & 25.5 & 12.4 & 8.3 & 191.8 & 4.0 \\
\hline Sg57 & 130 & 2.6 & 0.5 & 2.7 & 6.4 & 12.4 & 6.1 & 10.5 & 1.3 \\
\hline Ma58 & 20 & 2.0 & 0.5 & 2.4 & 4.9 & 6.9 & 6.1 & 16.4 & -4.5 \\
\hline Sb60 & 266 & 9.1 & 1.4 & 12.4 & 16.6 & 6.9 & 5.0 & 115.4 & 2.0 \\
\hline Ma63 & 106 & 3.3 & 0.7 & 3.8 & 8.2 & 6.9 & 8.2 & 36.2 & -4.5 \\
\hline
\end{tabular}


The correlation coefficient uses the Spearman method to determine the relationship between several hydrochemical parameters. The relationship between variables was analyzed using the Spearman method processed because the data observations are random samples with a uniform distribution (Table 3). Correlation analysis was performed on the hydrochemical data of conductivity, TDS, $\mathrm{pH}, \mathrm{Ca}^{2+}, \mathrm{Mg}^{2+}, \mathrm{Na}^{+}, \mathrm{K}^{+}, \mathrm{SO}_{4}{ }^{2-}$, $\mathrm{Cl}^{-}, \mathrm{HCO}_{3}{ }^{-}, \mathrm{CO}_{3}{ }^{-}$.

The results of chemical and physical analysis of 26 samples with correlation analysis showed the dominance of $\mathrm{Ca}^{2+}>\mathrm{Na}^{+}>\mathrm{Mg}^{2+}$ cations and $\mathrm{HCO}_{3}^{-}>\mathrm{Cl}^{-}>\mathrm{SO}_{4}{ }^{2-}$ anions. The moderate to very strong correlation shows the dissolving reaction of rock minerals in groundwater. In the study area, almost all types showed the predominance of $\mathrm{Ca}^{2+}$ and $\mathrm{HCO}_{3}{ }^{-}$, followed by $\mathrm{Mg}^{2+}$ and $\mathrm{C}$, this condition is influenced by hydrochemical and geological formation [29]. The related ions are influenced by environmental and rock factors [30].

There are three groups of conductivity and TDS values:

(i) Group A, the upper zone is characterized by active groundwater flushing with low TDS value $<200 \mathrm{mg} / \mathrm{L}$ and conductivity $<300 \mu \mathrm{S} / \mathrm{cm}$, found in old volcanic deposits (Qopu) and Mt. Malabar volcanic Deposits (Qmt).

(ii) Group B, the intermediate zone is characterized by less active groundwater circulation, with moderate TDS value $200-300 \mathrm{mg} / \mathrm{L}$ and conductivity with values $170-460 \mu \mathrm{mhos} / \mathrm{cm}$, is present in the $\mathrm{Fm}$ Beser (Tmb) and lake deposits (Qd).

(iii) Group C, the lower zone is characterized by passive groundwater with a high TDS value $>300 \mathrm{mg} / \mathrm{L}$ and conductivity value of $<370 \mu \mathrm{mhos} / \mathrm{cm}$, is found in lake deposits (Qd) (Fig. 2). Sources of material availability from TDS and conductivity come from the geological conditions and the influence of human activities such as industry, households, and agriculture [31]. Variation in TDS values indicates groundwater recharge areas [6]. A high TDS value indicates the travel time for groundwater [32]. The TDS value caused by anthropogenic effects is validated by Nitrate concentrations (Fig. 3). High nitrate values are situated in livestock, and plantation areas were located in the Pangalengan. The average nitrate concentration in Pangalengan is $23.03 \mathrm{mg} / \mathrm{L}$. The nitrate concentration is getting lower downstream.

Groundwater hydrogeochemistry is controlled by several processes such as evaporation, precipitation, ion exchange, oxidation-reduction, weathering, and dissolving [32]. The $\mathrm{Ca}^{2+} / \mathrm{Mg}^{2+}$ molar ratio indicates the dissolution of calcite, dolomite, and silicate. The ratio of $\mathrm{Ca}^{2+} / \mathrm{Mg}^{2+}=1$ indicates dolomite dissolution, $\mathrm{Ca}^{2+} / \mathrm{Mg}^{2+}$ $>1$ ratio indicates calcite dissolution and ration $\mathrm{Ca}^{2+} / \mathrm{Mg}^{2+}>2$ ratio indicates silicate dissolution [33]. The dolomite dissolution occurs in Beser formation and volcanic deposits with $\mathrm{Ca}^{2+} / \mathrm{Mg}^{2+}$ values $0.73-0.81 \mathrm{meq} / \mathrm{L}$.

Table 3. Matrix of Spearman's correlation

\begin{tabular}{|c|c|c|c|c|c|c|c|c|c|c|c|c|}
\hline Parameter & $\mathrm{pH}$ & $\begin{array}{c}\text { Temp } \\
\left({ }^{\circ} \mathrm{C}\right)\end{array}$ & $\begin{array}{c}\text { Cond } \\
(\mu \mathrm{S} / \mathrm{cm})\end{array}$ & $\begin{array}{c}\text { TDS } \\
(\mathrm{mg} / \mathrm{L})\end{array}$ & $\begin{array}{c}\mathrm{Na}^{+} \\
(\mathrm{mg} / \mathrm{L})\end{array}$ & $\begin{array}{c}\mathrm{K}^{+} \\
(\mathrm{mg} / \mathrm{L})\end{array}$ & $\begin{array}{c}\mathrm{Mg}^{2+} \\
(\mathrm{mg} / \mathrm{L})\end{array}$ & $\begin{array}{c}\mathrm{Ca}^{2} \\
(\mathrm{mg} / \mathrm{L})\end{array}$ & $\begin{array}{c}\mathrm{Cl}^{-} \\
(\mathrm{mg} / \mathrm{L})\end{array}$ & $\begin{array}{c}\mathrm{SO}_{4}{ }^{2-} \\
(\mathrm{mg} / \mathrm{L})\end{array}$ & $\begin{array}{l}\mathrm{HCO}_{3}^{-} \\
(\mathrm{mg} / \mathrm{L})\end{array}$ & $\begin{array}{c}\mathrm{CO}_{3}^{-} \\
(\mathrm{mg} / \mathrm{L})\end{array}$ \\
\hline $\mathrm{pH}$ & 1.00 & & & & & & & & & & & \\
\hline Temp & 0.53 & 1.00 & & & & & & & & & & \\
\hline Cond & 0.56 & 0.46 & 1.00 & & & & & & & & & \\
\hline TDS & 0.56 & 0.25 & 0.83 & 1.00 & & & & & & & & \\
\hline $\mathrm{Na}^{+}$ & 0.54 & 0.31 & 0.86 & 0.73 & 1.00 & & & & & & & \\
\hline $\mathrm{K}^{+}$ & 0.53 & 0.33 & 0.68 & 0.46 & 0.67 & 1.00 & & & & & & \\
\hline $\mathrm{Mg}^{2+}$ & 0.36 & 0.39 & 0.80 & 0.68 & 0.62 & 0.49 & 1.00 & & & & & \\
\hline $\mathrm{Ca}^{2+}$ & 0.37 & 0.43 & 0.85 & 0.77 & 0.57 & 0.50 & 0.79 & 1.00 & & & & \\
\hline $\mathrm{Cl}$ & 0.08 & 0.02 & 0.59 & 0.47 & 0.73 & 0.35 & 0.38 & 0.35 & 1.00 & & & \\
\hline $\mathrm{SO}_{4}^{2-}$ & -0.36 & -0.43 & -0.14 & -0.09 & 0.06 & -0.08 & -0.14 & -0.05 & 0.26 & 1.00 & & \\
\hline $\mathrm{HCO}_{3}^{-}$ & 0.64 & 0.59 & 0.87 & 0.74 & 0.64 & 0.67 & 0.81 & 0.85 & 0.20 & -0.30 & 1.00 & \\
\hline $\mathrm{CO}_{3}{ }^{-}$ & 0.30 & 0.09 & 0.44 & 0.44 & 0.43 & 0.13 & 0.36 & 0.46 & 0.32 & -0.02 & 0.32 & 1.00 \\
\hline
\end{tabular}




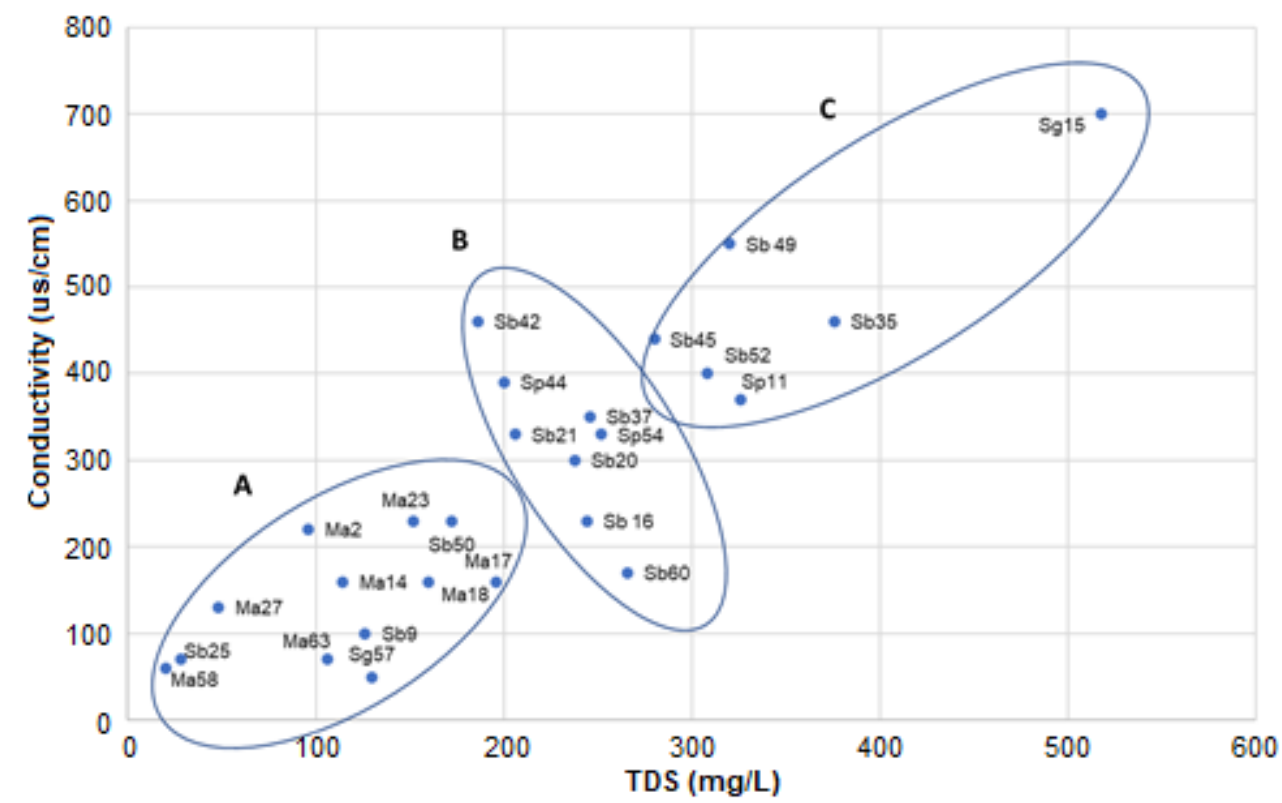

Fig 2. Groundwater conductivity correlation to TDS

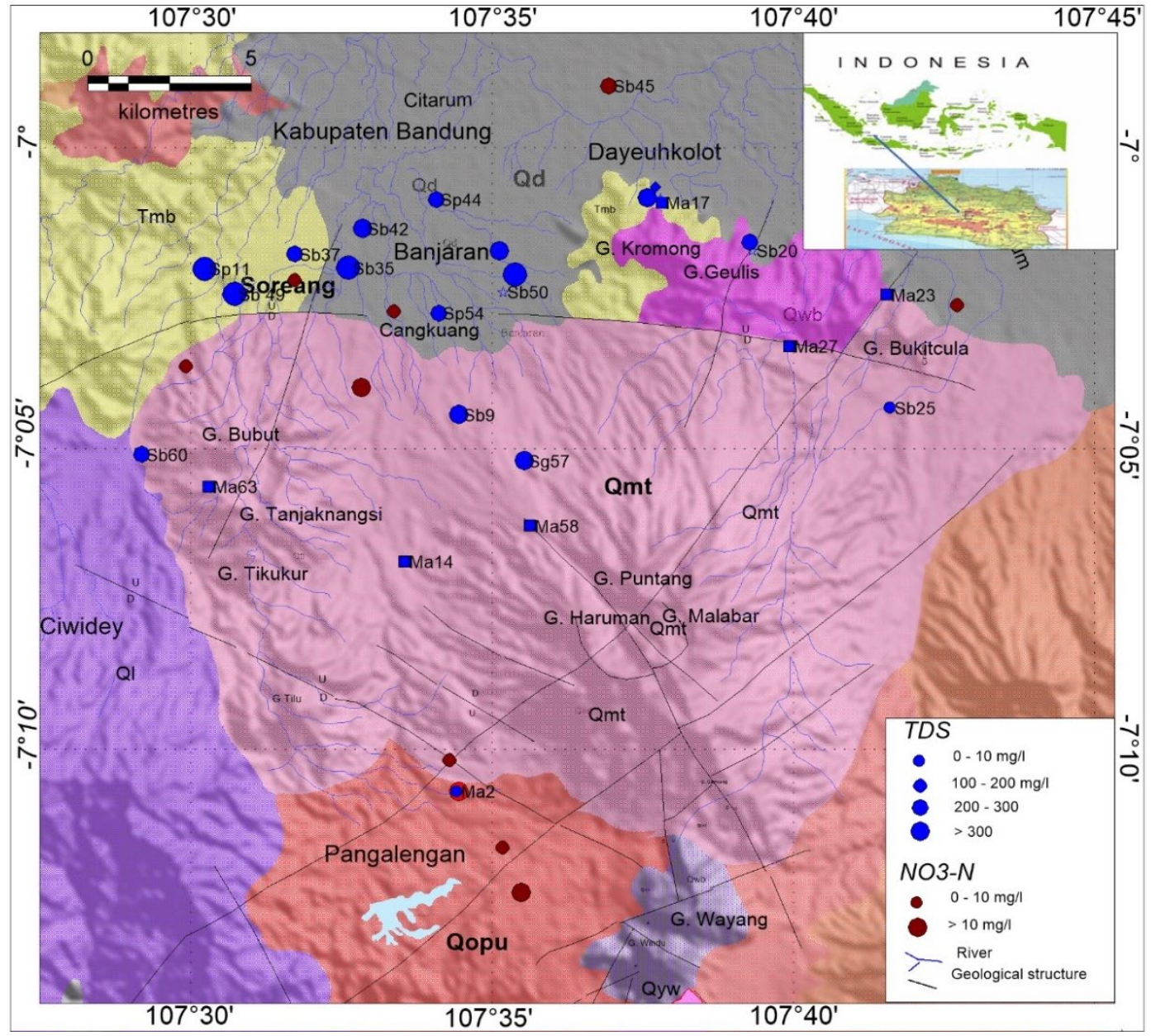

Fig 3. TDS and $\mathrm{NO}_{3}-\mathrm{N}$ concentration in the research area 
Calcite dissolution dominates the entire area with even distribution of volcanic deposits and lake sediments with $\mathrm{Ca}^{2+} / \mathrm{Mg}^{2+}$ values $1.00-1.81 \mathrm{meq} / \mathrm{L}$. Silicate weathering occurs in Beser formation and lake sediments with $\mathrm{Ca}^{2+} / \mathrm{Mg}^{2+}$ values $2.28-3.93 \mathrm{meq} / \mathrm{L}$. The dominance of groundwater in the study area is influenced by calcite minerals dissolution (Fig. 4). The relatively high value of the $\mathrm{Ca}^{2+} / \mathrm{Mg}^{2+}$ ratio indicates that the interaction process between rock and water is quite long.

Groundwater hydrochemical processes control the mechanism of groundwater originating from the dominance of rainwater, rock weathering, crystallization, or evaporation. The TDS process in groundwater evolution has a low value, and the composition of the dominant bicarbonate ion shows the water source comes from shallow aquifers [33].The Gibbs diagram distinguishes the effects of rock weathering interactions, evaporation, and the impact of rainwater on groundwater chemical processes [34]. Based on the analysis, rock weathering has influenced the groundwater chemical process (Fig. 5, 6).

The ratio of TDS to $\mathrm{Cl}^{-} /\left(\mathrm{Cl}^{-}+\mathrm{HCO}_{3}^{-}\right)$anions show that the groundwater is affected by rock weathering (Fig. 5). Group A consists of Ma2 and Sg57, which are springs and dug wells in the volcanic deposits area in the proximal facies. Group A has a high $\mathrm{Cl}$ value due to the influence of hydrothermal alteration. Group B consists of Sg15, Sb52, Sb49, and Sp11, located in lake deposits and

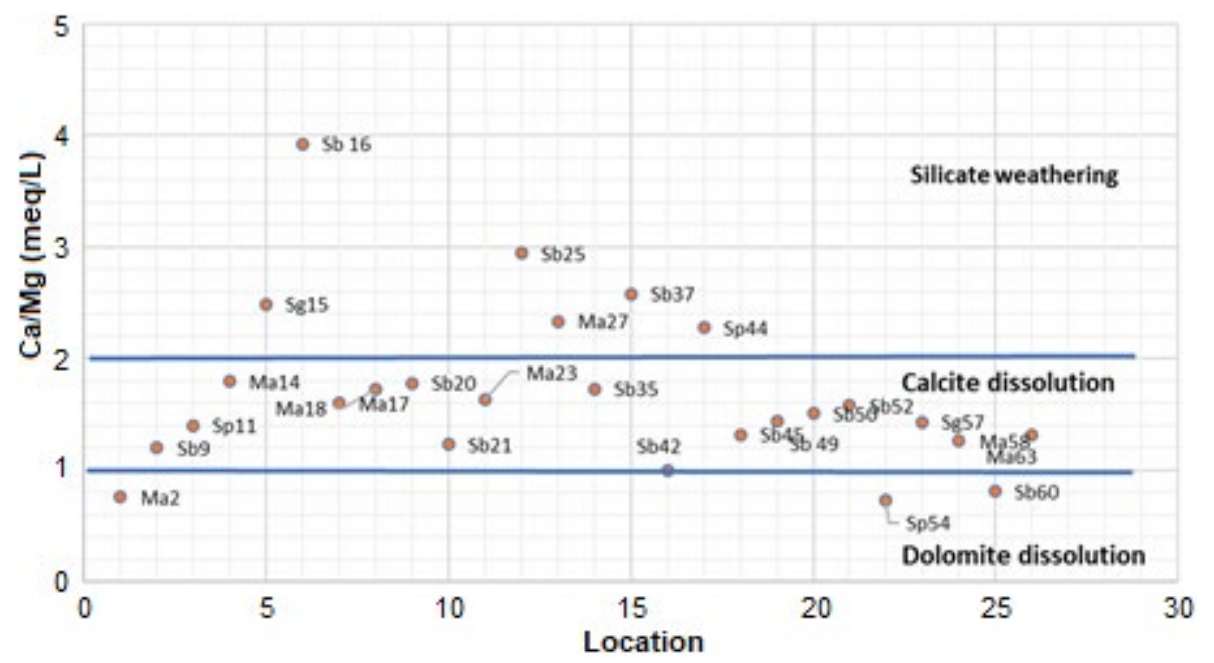

Fig 4. Bivariate $\mathrm{Ca}^{2+} / \mathrm{Mg}^{2+}$ in the study area

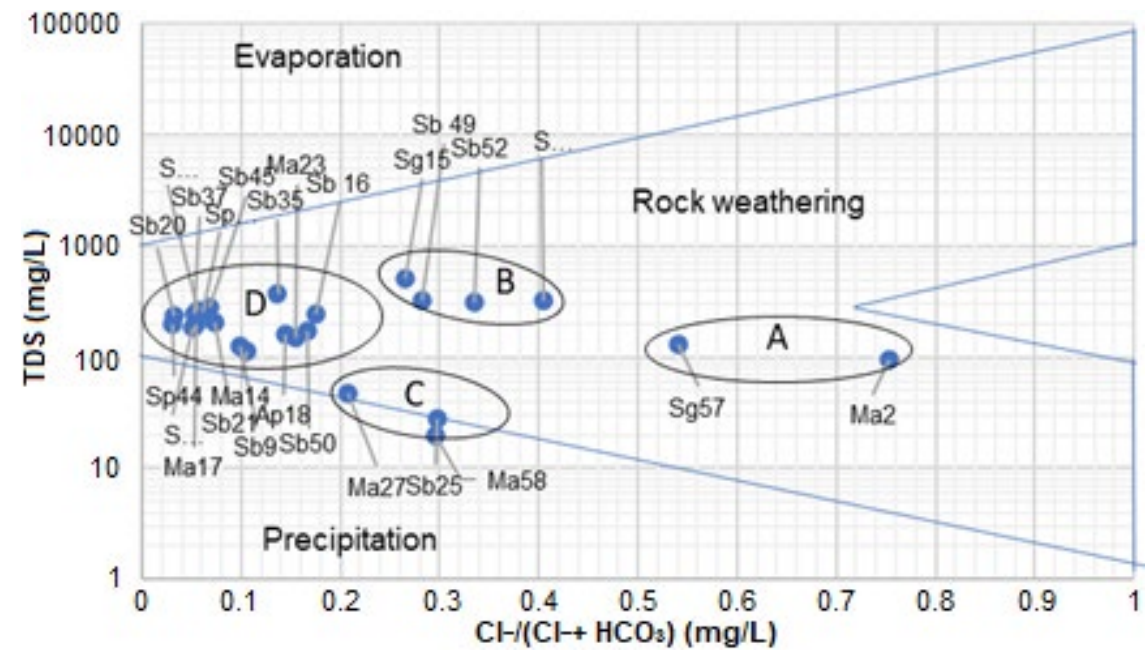

Fig 5. Gibbs diagram of the ratio of TDS with anion $\mathrm{Cl}^{-} /\left(\mathrm{Cl}^{-}+\mathrm{HCO}_{3}\right)$ 


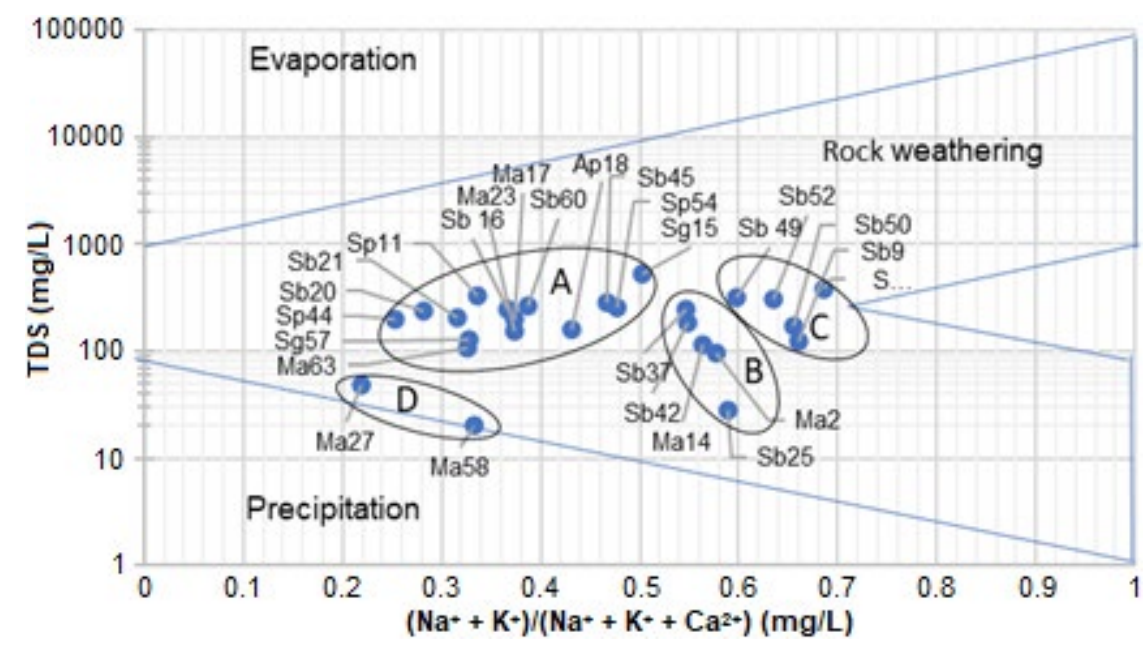

Fig 6. Gibbs diagram of the ratio of TDS with cations $\left(\mathrm{Na}^{+}+\mathrm{K}^{+}\right) /\left(\mathrm{Na}^{+}+\mathrm{K}^{+}+\mathrm{Ca}^{2+}\right)$

Beser formation deposits in the distal facies. Higher TDS values in group $B$ indicate this area is much influenced by anthropogenic activity. Group C consists of Sb25, ma27, ma58, which are water sources located in the Malabar volcanic deposits and Beser formation deposits in the medial facies. Group $\mathrm{C}$ has low TDS and $\mathrm{Cl}^{-}$values because it comes from springs in the hills with little anthropogenic influence. Group D is groundwater in the medial and distal facies. The TDS value in group D is high due to anthropogenic effects.

The ratio of TDS to the cation $\left(\mathrm{Na}^{+}+\mathrm{K}^{+}\right) /\left(\mathrm{Na}^{+}+\mathrm{K}^{+}\right.$ $\left.+\mathrm{Ca}^{2+}\right)$ shows that the groundwater is affected by rock weathering (Fig. 6). Group A consists of Ma2, ma14, Sb25, Sb37, and Sb42, springs, and drilling wells in volcanic deposits in the proximal and medial facies. Higher TDS in group A indicate anthropogenic influenced activity. Group B consists of Sb9, Sb35, Sb49, Sb50, and Sb52, deep groundwater drilling wells located in lake deposits, and Beser formation deposits in the distal facies. Groundwater in Type $\mathrm{C}$ is located in the medial and distal facies. Group D consists of ma27 and ma58, water resources located in the Malabar volcanic deposits, and Beser formation deposits in the medial facies. Differences in each group of these facies show rock properties greatly influence groundwater chemistry. The high ratio of $\mathrm{HCO}_{3}{ }^{-}$shows rock weathering as a major ion[32]. Hydrochemical conditions are a reflection of the length of the short residence time in the aquifer. The longer groundwater interacts and circulates in the aquifer, the total dissolved solids' total concentration will increase until it reaches an equilibrium condition.

The cation exchange process indicates the interaction between rock and groundwater occurs for a long time. The plot of $\left(\mathrm{Ca}^{2+}+\mathrm{Mg}^{2+}\right)-\left(\mathrm{HCO}_{3}{ }^{-}-\mathrm{SO}_{4}{ }^{2-}\right)$ versus $\mathrm{Na}^{+}-\mathrm{Cl}^{-}$was prepared to evaluate the ionexchange process [33]. The dominant process of ion exchange will form a line with a slope of -1 . The reverse ion exchange will form a line with a slope of $>1$. It can be explained by the following reaction [35].

$\mathrm{Ca}^{2+}\left(\mathrm{Mg}^{2+}\right)+\mathrm{Na}^{+}$(clay) $\leftrightarrow 2 \mathrm{Na}^{+}+\mathrm{CaMg}$ (clay)

The ion exchange process is located in Sb52, Ma63, Ma58, Ma27, Sg57, Sg15, Ma2, Sp11. The reverse ion exchange is dominated in the area (Fig. 7).

\section{Hydrochemical Facies}

The shallow groundwater tends to be influenced by local rainwater infiltration. It has a low bicarbonate concentration. However, the deep groundwater has a higher bicarbonate concentration than shallow groundwater; the process of deep groundwater from the recharge area dissolves more carbonate rocks [34]. To determine the hydrochemical facies and groundwater characteristics, the hydrochemical data is plotted on the Piper diagram [8]. Based on the piper diagram analysis, the dominant types of hydrochemical facies are $\mathrm{CaCl}$, $\mathrm{CaMgCl}, \mathrm{CaMgHCO}, \mathrm{CaHCO}_{3}$, and $\mathrm{NaKHCO}_{3}$ (Fig. 8). 


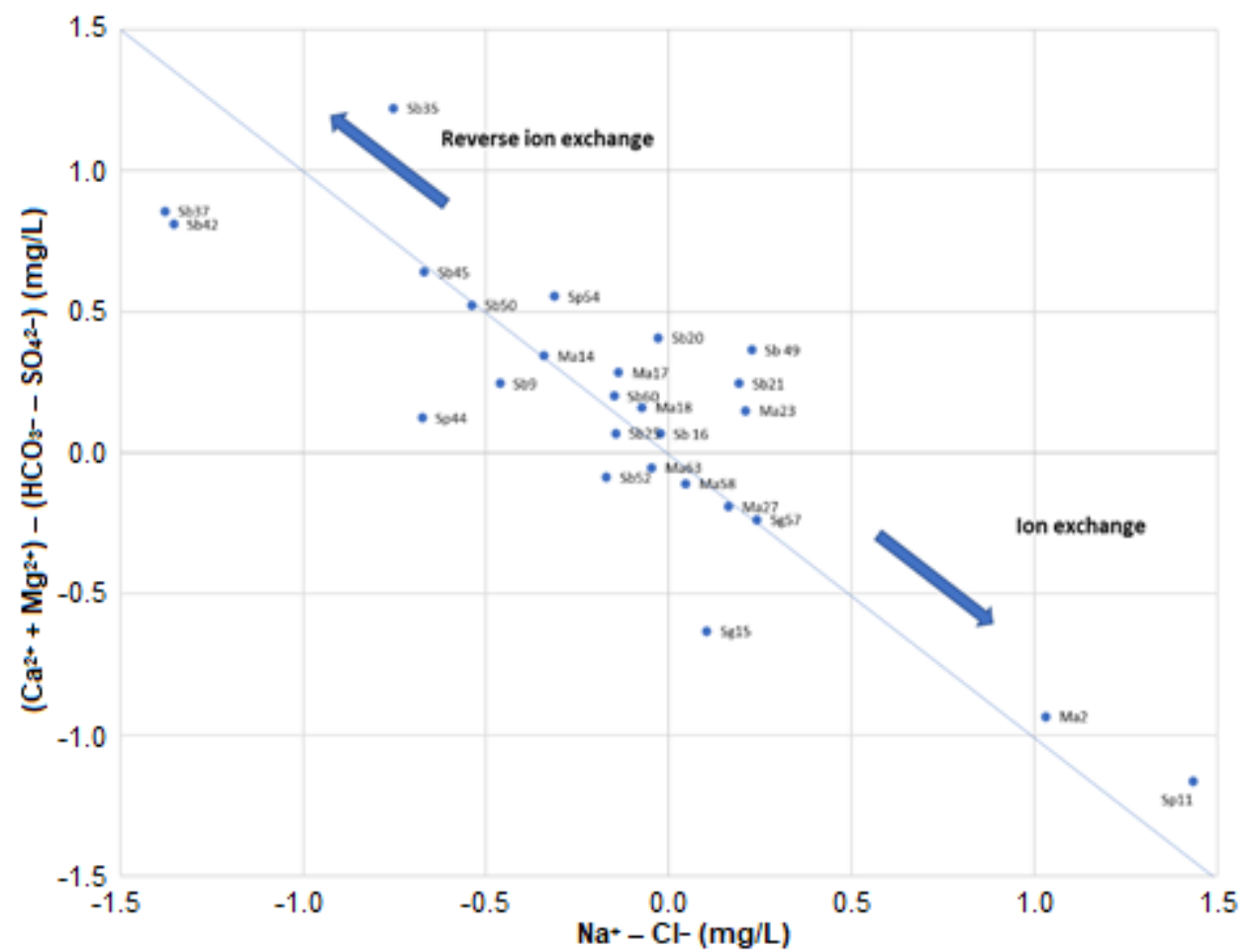

Fig 7. Bivariate $\left(\mathrm{Ca}^{2+}+\mathrm{Mg}^{2+}\right)-\left(\mathrm{HCO}_{3}{ }^{-}-\mathrm{SO}_{4}{ }^{2-}\right)$ versus $\mathrm{Na}^{+}-\mathrm{Cl}^{-}$in the study area

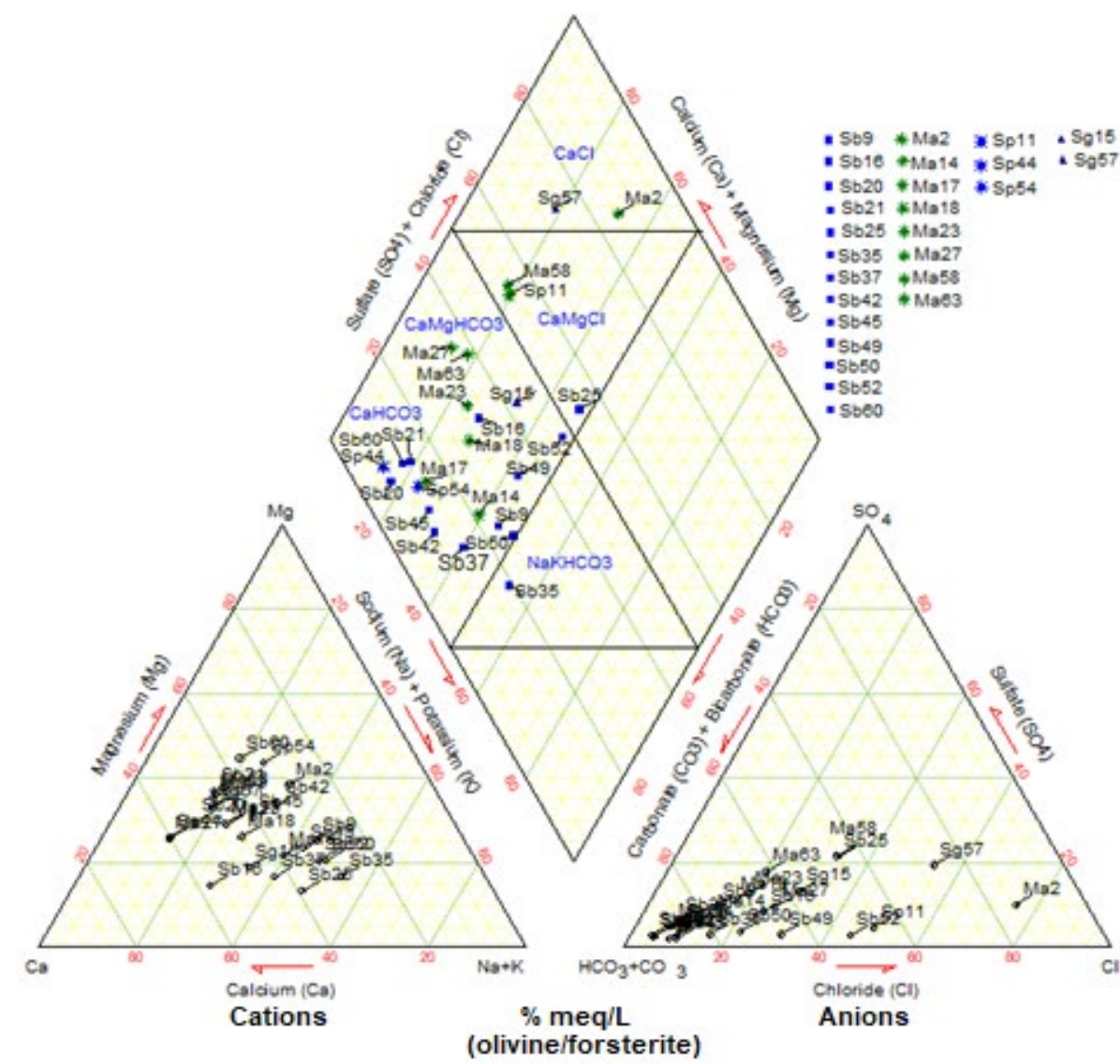

Fig 8. Piper diagram of the groundwater samples 
The groundwater $\mathrm{CaCl}$ facies are located at $\mathrm{Sg} 57$ and $\mathrm{Ma} 2$ in the central volcano facies. These facies lies in the hydrothermal alteration zone. $\mathrm{Cl}^{-}$ions' density comes from the weathering of the feldspathoid sodalite mineral $\left(\mathrm{Na}_{2} \mathrm{Cl}_{2} \cdot \mathrm{Al}_{2} \mathrm{SiO}_{4}\right)$ as a constituent of porous volcanic rock [35]. Several factors that cause $\mathrm{Cl}^{-}$enrichment in the study area are contamination of geothermal fluids and anthropogenic effects.

The CaMgCl facies in the Ma58 and Sp11 locations in the Malabar Tilu volcanic deposit. The calciummagnesium dominance is generated from the weathering of silica minerals rich in $\mathrm{Ca}^{2+}$ from basaltic andesitic volcanic rocks. Aquifers are formed by coarse tuff alternating basalt lava. The constituent minerals are feldspar (albite-labradorite, olivine, pyroxene, and chlorite [35]. The weathering process of aquifer constituent minerals is described as follows:

$$
\begin{aligned}
& \mathrm{Mg}_{2} \mathrm{SiO}_{4}(\mathrm{~s})+4 \mathrm{H}_{2} \mathrm{O} \leftrightarrow 2 \mathrm{Mg}^{2+}+4 \mathrm{OH}^{-}+\mathrm{H}_{2} \mathrm{SO}_{4} \\
& \text { (Forsterite) } \\
& 2 \mathrm{NaAlSi}_{3} \mathrm{O}_{8}+2 \mathrm{CO}_{2}+3 \mathrm{H}_{2} \mathrm{O} \leftrightarrow 2 \mathrm{Na}^{+}+2 \mathrm{HCO}_{3}{ }^{-}+4 \mathrm{SiO}_{2}(\mathrm{~s}) \\
& \text { (Albite) } \\
& +\mathrm{Al}_{2} \mathrm{Si}_{2} \mathrm{O}_{5}(\mathrm{OH})_{4}(\mathrm{~s}) \\
& \text { (Kaolinite) }
\end{aligned}
$$

$\mathrm{CaFeSi}_{2} \mathrm{O}_{4}+8 \mathrm{H}^{+}+\mathrm{O}_{2}+6 \mathrm{H}_{2} \mathrm{O} \leftrightarrow 4 \mathrm{Ca}^{2+}+4 \mathrm{FeOOH}+8 \mathrm{H}_{2} \mathrm{SiO}_{4}$ (Pyroxene-augite)

The $\mathrm{CaMgHCO}_{3}$ is dominates the hydrochemical type in the Malabar Tilu volcanic deposits. This is located in Ma14, Ma17, Ma18, Ma23, Ma27, Ma63, Sg15, Sp54, Sb18, Sb9, Sb16, Sb37, Sb42, Sb45, Sb49, Sb50, Sb52, Sb54. This type is formed due to the interaction between rocks and groundwater for a long time due to mixing, this can be seen from the amount of enrichment of $\mathrm{Ca}^{2+}$ and $\mathrm{Mg}^{2+}$ ions balanced.

The $\mathrm{CaHCO}_{3}$ facies are at locations Sp44, Sb20, $\mathrm{Sb} 21$, Sb60 scattered in the proximal and medial facies. This group shows that groundwater circulation is not too far away. The dominant $\mathrm{Ca}^{2+}$ content is due to the interaction with volcanic rocks. The presence of $\mathrm{HCO}_{3}{ }^{-}$ indicates that the groundwater has been mixed with shallow groundwater as a local recharge. The presence of $\mathrm{Ca}^{2+}$ cations is affected by the weathering of rocks, while bicarbonate anions $\left(\mathrm{HCO}_{3}{ }^{-}\right)$is influenced by the time of storing water in rocks and the atmospheric condition [8]. The chemical reaction indicates weathering process of the minerals $\mathrm{CaHCO}_{3}$ facies [35]:
$\mathrm{CaFeSiO}_{4}+8 \mathrm{H}^{+}+\mathrm{O} 2+6 \mathrm{H}_{2} \mathrm{O} \leftrightarrow 4 \mathrm{Ca}^{2+}+4 \mathrm{FeOOH}+8 \mathrm{H}_{2} \mathrm{SiO}_{4}$ (Pyroxene-augite)

The $\mathrm{NaKHCO}_{3}$ facies are located at $\mathrm{Sb} 35$, scattered on distal facies. Volcanic deposit rocks have mineral compositions of $\mathrm{Na}$-feldspar $\left(\mathrm{NaAlSi}_{3} \mathrm{O}_{8}\right)$, K-feldspar $\left(\mathrm{KAl}_{2} \mathrm{Si}_{2} \mathrm{O}_{8}\right)$, pyroxene $\left(\mathrm{KAlSi}_{3} \mathrm{O}_{8}\right)$, and olivine $\left(\mathrm{Mg}_{2} \mathrm{SiO}_{4}\right)$ [35]. The result of the weathering of these rock minerals is the source of the presence of $\mathrm{Na}^{+}$cations and $\mathrm{HCO}_{3}{ }^{-}$ anions.

The reaction indicates the formation of $\mathrm{NaKHCO}_{3}$ facies [35]: $\begin{aligned} 2 \mathrm{NaAlSi}_{3} \mathrm{O}_{8}+2 \mathrm{CO}_{2}+3 \mathrm{H}_{2} \mathrm{O} \leftrightarrow & 2 \mathrm{Na}^{+}+2 \mathrm{HCO}_{3}+4 \mathrm{SiO}_{2}(\mathrm{~s}) \\ & +\underset{\text { (klbite) }}{\mathrm{Al}_{2} \mathrm{Si}_{2} \mathrm{O}_{3}(\mathrm{OH})_{4}(\mathrm{~s})} \\ & \text { (kaolinite) }\end{aligned}$

$2 \mathrm{KAlSi}_{3} \mathrm{O}_{8}+8 \mathrm{H}^{+}+\mathrm{O} 2+6 \mathrm{H}_{2} \mathrm{O} \leftrightarrow 4 \mathrm{Ca}^{2+}+4 \mathrm{FeOOH}+8 \mathrm{H}_{2} \mathrm{SiO}_{4}$ (Pyroxene-augite)

$\mathrm{Mg}_{2} \mathrm{SiO}_{4}(\mathrm{~s})+4 \mathrm{H}_{2} \mathrm{O} \leftrightarrow \mathrm{Mg}^{2+}+\mathrm{HCO}_{3}{ }^{-}+\mathrm{H}_{2} \mathrm{SO}_{4}{ }^{2-}$

The cation exchange process in groundwater evolution is characterized by decreasing $\mathrm{Ca}^{2+}$ and $\mathrm{Mg}^{2+}$ values and enriching $\mathrm{Na}^{+}$values [8]. $\mathrm{Na}^{+}$ions' enrichment is due to the cation exchange process between $\mathrm{Ca}^{2+}$ ions and $\mathrm{Mg}^{2+}$ ions, and it becomes $\mathrm{Na}^{+}$ ions. In the research area, this process occurs in the distal area because there are many clay inserts. The adsorption rate of $\mathrm{Na}^{+}$cations on clay minerals tends to be weaker than that of $\mathrm{Ca}^{2+}$ ions. The adsorption tendencies among the main cations are [32]: (strong adsorption) $\mathrm{Ca}^{2+}<$ $\mathrm{Mg}^{2+}<\mathrm{K}^{+}<\mathrm{Na}^{+}$(weakly adsorbed).

\section{Stable isotopes to determine groundwater recharge}

The stable isotopes $\delta^{18} \mathrm{O}$ and $\delta^{2} \mathrm{H}$ have varying ratios related to elevation functions and rainfall values. The various isotopic compositions can be grouped using local meteoric lines (LMWL), determining groundwater processes, i.e., groundwater and rock interactions, evaporation, and mixing processes [21]. Analysis of the recharge area with stable isotope requires three types of isotope graphs, the local meteoric water line (LMWL) graph, the depletion gradient graph $\delta^{18} \mathrm{O}$ for elevation, and the depletion gradient graph $\delta^{2} \mathrm{H}$ for height [27].

The Local Meteoric water line (LMWL) determination uses research from the Geological Agency [17], which observed rainfall isotopes from January 2008 to July 2009. The stations selected in the study area were 
PT. Safilindo, Cikalong hydropower, and Malabar plantation (Table 4). The equation of the local meteoric line (LMWL) from the measurement results [17] with the equation:

$\delta^{2} \mathrm{H}=8.3 \delta^{18} \mathrm{O}+14.3$

$\mathrm{R}^{2}=0.9873$
Data on the results of physical measurements of $\delta^{18} \mathrm{O}$ and $\delta{ }^{2} \mathrm{H}$ isotopes in groundwater in the southern Bandung groundwater basin are shown in Table 5.

Groundwater isotope values were plotted on the Bandung Meteoric Water to determine the relationship between groundwater and meteoric water (Fig. 9) and also

Table 4. Rainwater isotope $\delta^{18} \mathrm{O}$ and $\delta^{2} \mathrm{H}$ analysis for the period of January 2008-July 2009

\begin{tabular}{lcccccc}
\hline \multirow{2}{*}{ Month } & \multicolumn{2}{c}{ PT Safilindo $(829 \mathrm{~m}$ asl $)$} & \multicolumn{2}{c}{ Cikalong $(1255 \mathrm{~m}$ asl $)$} & \multicolumn{2}{c}{ Malabar $(1560 \mathrm{~m} \mathrm{asl})$} \\
\cline { 2 - 7 } & $\delta^{18} \mathrm{O}(\%)$ & $\delta^{2} \mathrm{H}(\%)$ & $\delta^{18} \mathrm{O}(\%)$ & $\delta^{2} \mathrm{H}(\% \circ)$ & $\delta^{18} \mathrm{O}(\% \mathrm{o})$ & $\delta^{2} \mathrm{H}(\% \mathrm{o})$ \\
\hline 16-May-08 & -5.40 & -31.1 & -5.04 & -26.1 & - & - \\
13-Jun-08 & -3.48 & -10.4 & -3.43 & -13.0 & - & - \\
14-Jul-08 & -2.71 & -10.7 & - & - & -6.53 & -37.2 \\
13-Agt-08 & -3.99 & -20.0 & -4.23 & -17.0 & - & - \\
14-Sep-08 & -3.88 & -17.3 & -4.16 & -17.0 & -5.41 & -27.6 \\
13-Oct-08 & - & - & - & - & -5.18 & -24.7 \\
12-Nov-08 & -6.58 & -45.0 & -6.38 & -36.3 & -6.72 & -43 \\
13-Dec-08 & -8.65 & -55.4 & -10.9 & -73.1 & -10.95 & -73.5 \\
13-Jan-09 & -11.49 & -77.4 & -9.68 & -68.1 & -11.35 & -80.6 \\
13-Feb-09 & -8.54 & -57.2 & -10.13 & -70.6 & -10.65 & -73.2 \\
13-Mar-09 & -9.83 & -66.6 & -8.61 & -58.4 & -9.66 & -65.9 \\
13-Apr-09 & -6.88 & -47.3 & -6.22 & -40.8 & -7.37 & -49.2 \\
14 May 09 & -5.96 & -38.5 & -6.30 & -38.5 & -9.03 & -57.9 \\
15-Jun-09 & -7.98 & -48.9 & -7.73 & -45.8 & -7.30 & -45.05 \\
13-Jul-09 & -1.81 & -1.6 & -3.22 & -12.0 & -4.66 & -24.2 \\
Average & -6.22 & -37.7 & -6.62 & -39.7 & -7.90 & -50.17 \\
\hline
\end{tabular}

Table 5. Physical measurements of $\delta^{18} \mathrm{O}$ and $\delta^{2} \mathrm{H}$ isotopes in the southern Bandung

\begin{tabular}{rlccccc}
\hline No & Type of sample & $\mathrm{X}$ & $\mathrm{Y}$ & Elevation $(\mathrm{m})$ & $\delta^{18} \mathrm{O}(\%)$ & $\delta^{2} \mathrm{H}(\%)$ \\
\hline 1 & Ma2 & 784217 & 9205750 & 1427 & -8.56 & -53.5 \\
2 & Ma14 & 782672 & 9212796 & 915 & -6.51 & -42.0 \\
3 & Ma17 & 790591 & 9223757 & 718 & -7.01 & -42.4 \\
4 & Ma23 & 797460 & 9220890 & 716 & -6.58 & -41.1 \\
5 & Ma27 & 794474 & 9219337 & 855 & -7.61 & -47.2 \\
6 & Ma58 & 786522 & 9213881 & 1179 & -6.39 & -39.8 \\
7 & Ma63 & 776683 & 9215129 & 1222 & -7.12 & -43.5 \\
8 & Ma18 & 790159 & 9223906 & 720 & -5.86 & -36.1 \\
9 & Sb9 & 784363 & 9217295 & 809 & -8.02 & -47.7 \\
10 & Sb 16 & 790554 & 9223882 & 701 & -6.88 & -41.7 \\
11 & Sb20 & 793352 & 9222272 & 707 & -7.08 & -43.5 \\
12 & Sb21 & 793292 & 9222526 & 720 & -7.13 & -43.5 \\
13 & Sb25 & 797545 & 9217430 & 810 & -6.98 & -43.6 \\
14 & Sb35 & 781008 & 9221806 & 700 & -7.07 & -42.8 \\
15 & Sb37 & 779361 & 9222239 & 749 & -6.70 & -40.8 \\
16 & Sb42 & 781448 & 9223008 & 703 & -6.84 & -41.8 \\
17 & Sb45 & 788997 & 9227341 & 689 & -7.23 & -44.2 \\
18 & Sb 49 & 777512 & 9221024 & 734 & -6.91 & -42.2 \\
\hline
\end{tabular}

Rizka Maria et al. 
Table 5. Physical measurements of $\delta^{18} \mathrm{O}$ and $\delta^{2} \mathrm{H}$ isotopes in the southern Bandung (Continued)

\begin{tabular}{clccccc}
\hline No & Type of sample & $\mathrm{X}$ & $\mathrm{Y}$ & Elevation $(\mathrm{m})$ & $\delta^{18} \mathrm{O}(\% \mathrm{o})$ & $\delta^{2} \mathrm{H}(\% \mathrm{o})$ \\
\hline 19 & Sb50 & 785689 & 9920350 & 706 & -7.73 & -46.9 \\
20 & Sb52 & 786103 & 9221573 & 696 & -7.68 & -45.9 \\
21 & Sb60 & 774648 & 9216127 & 1059 & -7.03 & -43.8 \\
22 & Sp44 & 783701 & 9223886 & 692 & -5.46 & -34.4 \\
23 & Sp11 & 776614 & 9221798 & 816 & -6.85 & -44.3 \\
24 & Sg15 & 790418 & 9224231 & 700 & -6.85 & -43.5 \\
25 & Sg57 & 786348 & 9215868 & 965 & -6.58 & -41.4 \\
26 & Sp54 & 783759 & 9220403 & 705 & -6.08 & -38.8 \\
\hline
\end{tabular}

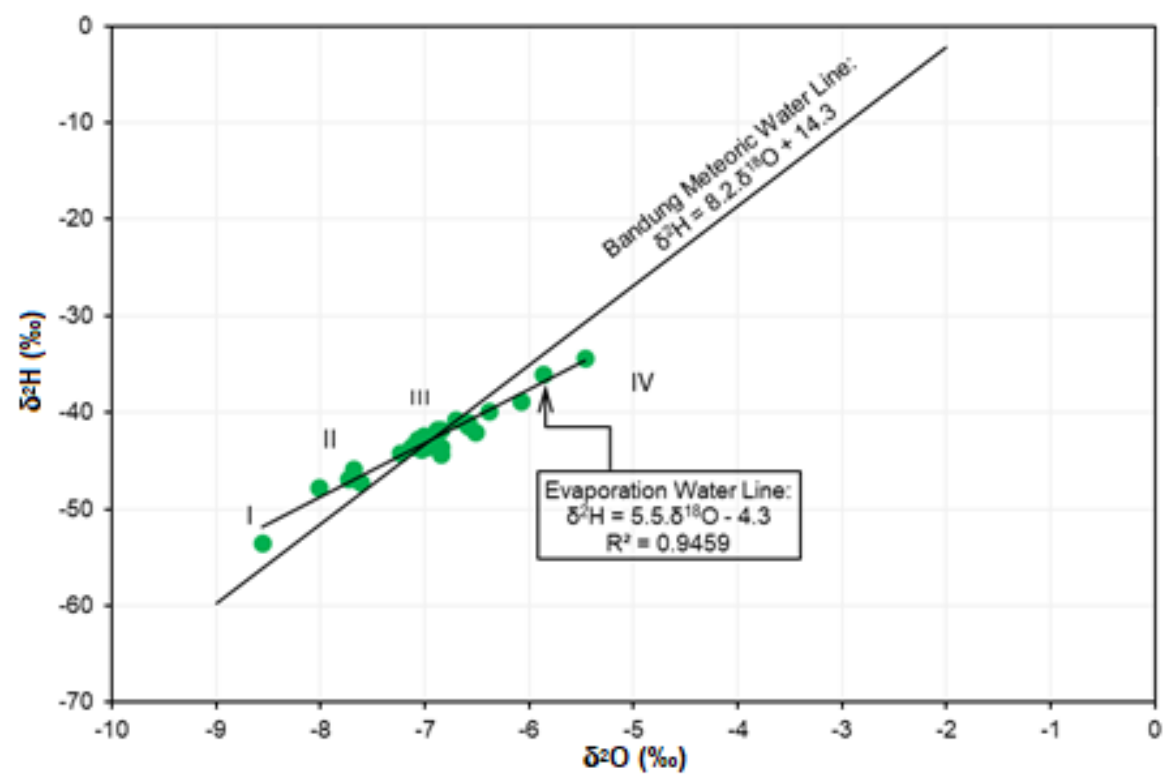

Fig 9. Relationship between $\delta^{2} \mathrm{H}$ and $\delta^{18} \mathrm{O}$ of groundwater in the study area

to estimate the elevation of the recharge area.

Furthermore, Fig. 10 shows the relationship between elevation and mean $\delta^{2} \mathrm{H}$ and $\delta^{18} \mathrm{O}$ isotopes of monthly rainwater.

Based on Fig. 10, the groundwater in the study area can be classified into four groups as follows:

(i) Group I: groundwater Ma2, which is at an elevation of $1427 \mathrm{~m}$ asl, from the $18 \mathrm{O}$ and $2 \mathrm{H}$ isotope values do not indicate water originating from a higher elevation and is considered water originating from local rainwater infiltration.

(ii) Group II: groundwater Ma27, Sb9, Sb50, and Sb52, which are at an elevation of $696-855 \mathrm{~m}$ asl, are considered to come from the same infiltration elevation, which ranges from $980-1230 \mathrm{~m}$ asl.
(iii)Group III: groundwater Ma17, Ma23, Sb16, Sb20, Sb21, Sb25, Sb35, Sb37, Sb42, Sb45, Sb49, Sp11, Sg15, which are at an elevation between 700-816 m asl is estimated to be derived from the recharge elevation between 750-970 m asl. Meanwhile, groundwater Ma63 and Sb60, which are in this group, from the $18 \mathrm{O}$ and $2 \mathrm{H}$ isotope values, more indicate local rainwater origin.

(iv) Group IV: groundwater Ma14, Ma58, Ma18, Sp44, Sg57, Sp54 are more likely to show symptoms of evaporation or interaction with surface water.

The hydrogeological system's identification in this study was based on hydrochemical and stable isotope analysis of $\delta^{18} \mathrm{O}$ and $\delta^{2} \mathrm{H}$. The $\mathrm{CaCl}$ facies is located in the hydrothermal alteration zone. $\mathrm{Cl}^{-}$ions' density comes 

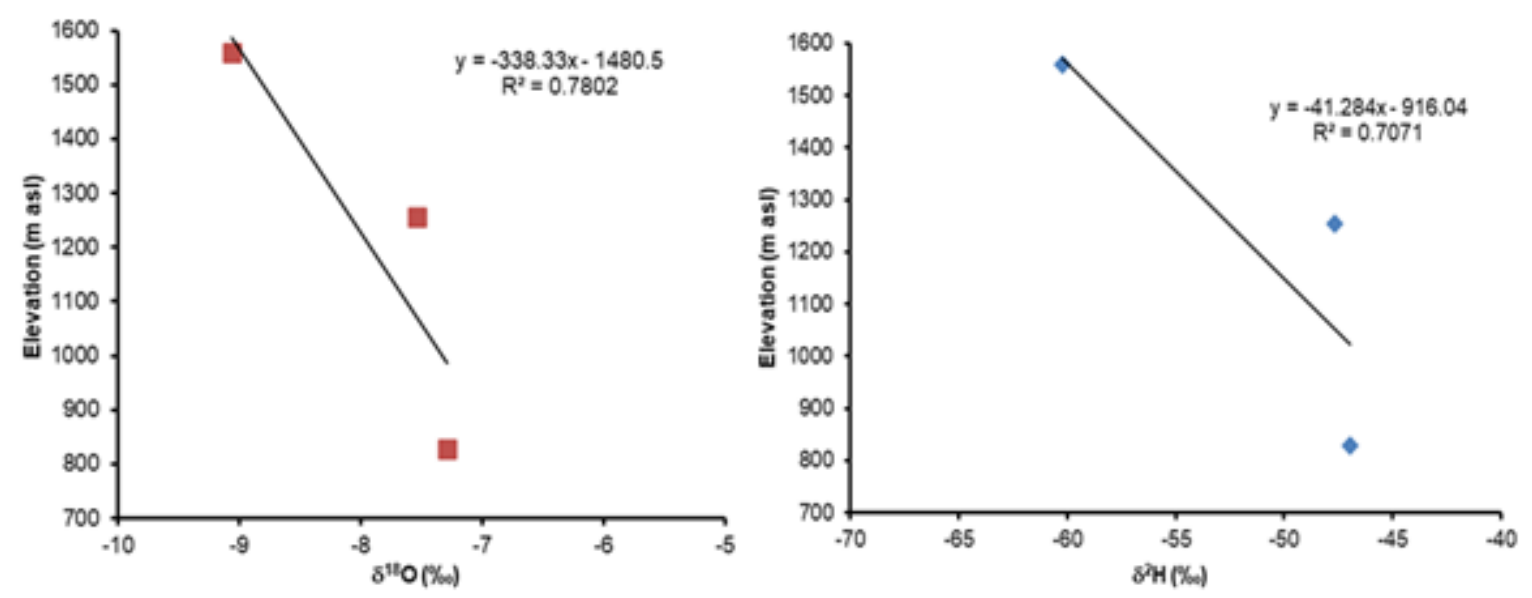

Fig 10. Graph of elevation vs. $\delta^{18} \mathrm{O}$ and $\delta^{2} \mathrm{H}$ in the study area

from contamination of geothermal fluids and the weathering of the feldspathoid sodalite mineral as a constituent of porous volcanic rock. The $\mathrm{CaMgCl}$ facies is a mixed water type. The calcium-magnesium dominance is generated from the weathering of silica minerals rich in $\mathrm{Ca}^{2+}$ from basaltic andesitic volcanic rocks. The $\mathrm{CaMgHCO}_{3}$ type is formed due to the interaction between rocks and groundwater for a long time due to mixing, this can be seen from the amount of enrichment of $\mathrm{Ca}^{2+}$ and $\mathrm{Mg}^{2+}$ ions tare balanced. The $\mathrm{CaHCO}_{3}$ facies shows groundwater circulation is not too far away. The dominant $\mathrm{Ca}^{2+}$ is due to the interaction with volcanic rocks. The presence of $\mathrm{HCO}_{3}{ }^{-}$indicates groundwater has been mixed with shallow groundwater as a local recharge.
The presence of $\mathrm{Ca}^{2+}$ cations comes from the weathering of rocks, while the presence of bicarbonate anions $\left(\mathrm{HCO}_{3}{ }^{-}\right)$is influenced by the time of storing water in rocks and the influence of the atmosphere. The $\mathrm{CaHCO}_{3}$ facies describe the groundwater flow with a short distance from shallow to moderate groundwater flows. The $\mathrm{NaKHCO}_{3}$ facies are on distal facies. The cation exchange process in groundwater evolution is characterized by decreasing $\mathrm{Ca}^{2+}$ and $\mathrm{Mg}^{2+}$ and enriching $\mathrm{Na}^{+}$ions. The adsorption rate of $\mathrm{Na}^{+}$cations on clay minerals tends to be weaker than $\mathrm{Ca}^{2+}$ ions. Groundwater facies $\mathrm{NaKHCO}_{3}$ shows groundwater flow intensity over a long-distance mixing shallow and deep groundwater (Fig. 11).

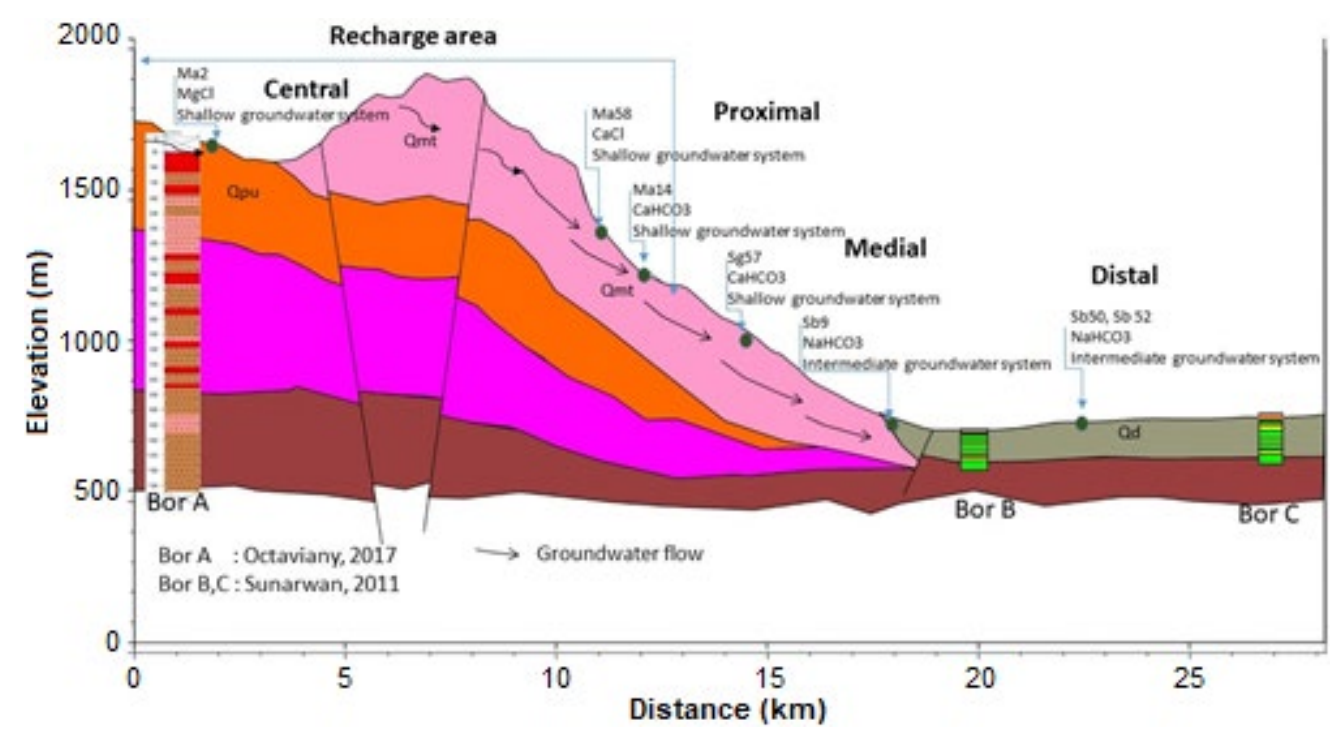

Fig 11. The hydrogeological system's identification in the study area 
Groundwater flow systems are classified into the middle flow or intermediate systems [1]. The concentration of TDS is also an indication of a recharge area. TDS has a low value in the central facies area and increases upward to the distal region. The catchment area located in the upper zone is characterized by active groundwater flushing with a low TDS value, seen in central and proximal facies. The discharge area is characterized by less active groundwater circulation, with dominant $\mathrm{HCO}_{3}{ }^{-}$and high TDS values are seen in the medial zone. The lower zone is characterized by passive groundwater with high sodium concentrations and TDS in distal facies.

Stable isotope analysis reveals irregular patterns, and localized catchments represent a complex hydrogeological system. Isotope analysis shows the groundwater recharge location follows the groundwater circulation flow. Groundwater in the study area can be classified into four groups as follows: Group I, which is at an elevation of $1427 \mathrm{~m}$ asl, from the ${ }^{18} \mathrm{O}$ and ${ }^{2} \mathrm{H}$ isotope values do not indicate water originating from a higher elevation and is considered water originating from local rainwater infiltration; Group II: which are at an elevation of 696-855 m asl, is considered to come from the same infiltration elevation, which ranges from $980-1230 \mathrm{~m}$ asl; Group III which are at an elevation between 700-816 m asl is estimated to be derived from the recharge elevation between 750-970 m asl, Group IV are more likely to show symptoms of evaporation or interaction with surface water.

\section{- CONCLUSION}

The results of hydrogeological, hydrochemical, and stable isotope analysis have determined groundwater recharge. The variation in groundwater chemistry of this area is principally controlled by a combination of ion exchange, silicate weathering, calcite, and dolomite dissolution of minerals. The hydrochemical facies were $\mathrm{CaCl}, \mathrm{CaMgCl}, \mathrm{CaMgHCO}_{3}, \mathrm{CaHCO}_{3}$, and $\mathrm{NaKHCO}_{3}$. Changes in $\mathrm{Ca}^{2+}$ to $\mathrm{Mg}^{2+}$ cations mean it has been a hydrochemical evolution. The $\mathrm{CaHCO}_{3}$ facies describe moderate groundwater flows. The $\mathrm{NaKHCO}_{3}$ Groundwater facies shows the mixing of shallow and deep groundwater into intermediate flow systems. The recharge area in the central, proximal, and medial facies zone consists of 4 groups. Group I, which is at an elevation of $1427 \mathrm{~m}$ asl, from the ${ }^{18} \mathrm{O}$ and ${ }^{2} \mathrm{H}$ isotope values do not indicate water originating from a higher elevation and is considered water originating from local rainwater infiltration; Group II: which are at an elevation of 696-855 m asl, are considered to come from the same infiltration elevation, which ranges from 980$1230 \mathrm{~m}$ asl; Group III which are at an elevation between $700-816 \mathrm{~m}$ asl is estimated to be derived from the recharge elevation between 750-970 m asl, Group IV are more likely to show symptoms of evaporation or interaction with surface water. The discharge area in the distal facies zone is characterized by less active groundwater circulation, with dominant $\mathrm{HCO}_{3}{ }^{-}$and TDS values. Hydrochemical variation helped the identification of recharge areas in the volcanic facies.

\section{- ACKNOWLEDGMENTS}

The author would like to thanks the Saintek Scholarship Program of the Ministry of Research and Technology, which has funded the education program. Thanks are also given to the Head of the Research Center for Geotechnology, Indonesian Institute of Science, Dr. Eko Yulianto, who has given permission for providing laboratory facilities to carry out the water sample analysis. Thanks are also given to Mr. Sudaryanto, MT, who has provided guidance.

\section{- AUTHOR CONTRIBUTIONS}

Rizka Maria conducted the experiment, calculations, wrote, and revised the manuscript. Satrio conducted, wrote, and revised the manuscript. TYWM Iskandarsyah conducted, wrote, and revised the manuscript. B.R. Suganda conducted, wrote, and revised the manuscript. M.R. Delinom revised the manuscript. Hendarmawan conducted, wrote, and revised the manuscript. D. Marganingrum provided guidance before wrote manuscript. Dady Sukmayadi and W. Purwoko have helped a lot in laboratory analysis. All authors agreed to the final version of this manuscript. 


\section{- REFERENCES}

[1] Hendarmawan, and Satrio, 2011, Recharge area on the slopes of volcano based on geological setting, content of deuterium and oxygen isotopes of groundwater chemistry: Case study on the slopes of Salak mountain, West Java, J. Trop. Soils, 16 (3), 245-256.

[2] Satrio, Hendarmawan, Hadian, M.S.D., and Pujiindiyati, E.R., 2016, Karakteristik air tanah dangkal kota Semarang pada musim penghujan berdasarkan pendekatan isotop stabil $\left({ }^{18} \mathrm{O},{ }^{2} \mathrm{H}\right)$ dan kimia air, J. Ilm. Apl. Isot. Radiasi, 11 (1), 73-86.

[3] Toulier, A., Baud, B., de Montety, V., Lachassagne, P., Leonardi, V., Pistre, V., Dautria, J.M., Hendrayana, H., Fajar, M.H.M., Muhammad, A.S., Beon, O., and Jourde, H., 2019, Multidisciplinary study with quantitative analysis of isotopic data for the assessment of recharge and functioning of volcanic aquifers: Case of Bromo-Tengger volcano, Indonesia, J. Hydrol.: Reg. Stud., 26, 100634.

[4] Abidi, J.H., Farhat, B., Ben Mammou, A., and Oueslati, N., 2017, Characterization of recharge mechanisms and sources of groundwater salinization in Ras Jbel coastal aquifer (Northeast Tunisia) using hydrogeochemical tools, environmental isotopes, GIS, and statistics, J. Chem., 2017, 8610894.

[5] Resubun, M.L., Wahjunie, E.D., and Tarigan, S.D., 2018, Analisis potensi ketersediaan dan kebutuhan air di Daerah Aliran Sungai Cisangkuy, JITL, 20 (2), 57-62.

[6] Hendrasto, F., and Sunarwan, B., 2013 Pemanfaatan isotop lingkungan di daerah cekungan airtanah Bandung, Jurnal Teknik, 14 (2), 1-11.

[7] Pujiindiyati, E.R., Satrio, and Prasetio, R., 2019, Major ions for tracing leachate migration within shallow ground water in the vicinity of municipal landfill in Bantar Gebang -Bekasi, Indones. J. Chem., 19 (1), 19-29.

[8] Krishnaraj, S., Murugesan, V., Vijayaraghavan, K., Sabarathinam, C., Paluchamy, A., and Ramachandran, M., 2011, Use of hydrochemistry and stable isotopes as tools for groundwater evolution and contamination investigations, Geosciences, 1 (1), 16-25.
[9] Wu, H., Chen, J., Qian, H., and Zhang, X., 2015, Chemical characteristics and quality assessment of groundwater of exploited aquifers in Beijiao water source of Yinchuan, China: A case study for drinking, irrigation, and industrial purposes, $J$. Chem., 2015, 726340.

[10] Hendarmawan, 2002, Unconfined aquifer system of volcanics in the northern part of Bandung basin, West Java, Indonesia, J. Geosci., Osaka City Univ., $45,1-12$.

[11] Delinom, R.M., and Suriadarma, A., 2010, Groundwater flow system of Bandung basin based on hydraulic head, subsurface temperature, and stable isotopes, JRGP, 20 (1), 55-68.

[12] Iskandar, I., Notosiswoyo, S., Purnandi, C., and Pasaribu, T., 2013, Type and origin of springs and hotsprings at surrounding ridges of Bandung basin, related with its potential natural contamination, Procedia Earth Planet. Sci., 6, 262-268.

[13] Sunarwan, B., 2011, Penentuan satuan hidrostratigrafi (HSU) di daerah volkanik (Studi kasus: Daerah cekungan Bandung), Jurnal Teknik, 12 (2), 44-56.

[14] Oktaviany, V., Hutabarat, J., and Haryanto, A.D., 2017, Estimasi temperatur bawah permukaan berdasarkan kehadiran mineral alterasi pada sumur ' $\mathrm{X}$ ' lapangan panas bumi Wayang Windu, Pangalengan, Kabupaten Bandung, Provinsi Jawa Barat, Bul. Sumber Daya Geol., 12 (2), 123-133.

[15] Taufiq, A., Effendi, A.J., Iskandar, I., Hosono, T., and Hutasoit, L.M., 2019, Controlling factors and driving mechanisms of nitrate contamination in groundwater system of Bandung basin, Indonesia, deduced by combined use of stable isotope ratios, CFC age dating, and socioeconomic parameters, Water Res., 148, 292-305.

[16] Suhendar, R., Hadian, M.S.D., Muljana, Setiawan, T., and Hendarmawan, 2020, Geochemical evolution and groundwater flow system in Batujajar groundwater basin area, West Java, Indonesia, Indones. J. Geosci., 7 (1) 87-104.

[17] Matahelumual, B.C., and Wahyudin, 2010, Penelitian hidrogeologi daerah imbuhan air tanah dengan 
metode isotop dan hidrokimia di cekungan air tanah Bandung- Soreang, Provinsi Jawa Barat (Tahap III), Field Report, Pusat Vulkanologi dan Mitigasi Bencana Geologi, Badan Geologi, Bandung, Indonesia.

[18] Bronto, S., Koswara, A., and Lumbanbatu, K., 2006, Stratigrafi gunung api daerah Bandung Selatan, Jawa Barat, Indones. J. Geosci., 1 (2), 89-101.

[19] Silitonga, P.H., 1973, Geologic Map of the Bandung Quadrangle, Java, scale 1:100.000, Geological Agency of the Ministry of Energy and Mineral Resources, Bandung, Indonesia.

[20] Alzwar, M., Akbar, N., and Bachri S., 1992, Peta geologi lembar Garut dan Pemeungpeuk, Jawa, Pusat Penelitian dan Pengembangan Geologi, Bandung.

[21] Clark, I., 2015, Groundwater Geochemistry and Isotopes, $1^{\text {st }}$ Ed., CRC Press, Boca Raton, Florida, US.

[22] Freeze, R.A., and Cherry, J.A., 1979, Groundwater, Prentice Hall, Inc., Englewood Cliffs, New Jersey.

[23] Ahamed, A.J., Loganathan, K., Ananthakrishnan, S., Ahmed, J.K.C., and Ashraf, M.A., 2016, Evaluation of graphical and multivariate statistical methods for classification and evaluation of groundwater in Alathur block, Perambalur District, India, Appl. Ecol. Environ. Res., 15 (3), 105-116.

[24] Gaikwad, S., Gaikwad, S., Meshram, D., Wagh, V., Kandekar, A., and Kadam, A., 2020, Geochemical mobility of ions in groundwater from the tropical western coast of Maharashtra, India: Implication to groundwater quality, Environ. Dev. Sustain., 22 (3), 2591-2624.

[25] Pujiindiyati, E.R., Sidauruk, P., Prayogi, T.E., and Abdillah, F., 2020, Hydrochemical evolution in Ciliwung River - Java, Indonesia: Study of sea water mixture and mineral dissolution, Indones. J. Chem., 20 (6), 1360-1373.

[26] Mohamed, A.K., Liu, D., Song, K., Mohamed, M.A.A., Aldaw, E., and Elubid, B.A., 2019, Hydrochemical analysis and fuzzy logic method for evaluation of groundwater quality in the North Chengdu plain, China, Int. J. Environ. Res. Public Health, 16 (3), 302.
[27] Mook, W.G., 2001, Environmental Isotopes in the Hydrological Cycle: Principles and Applications, Volume I: Introduction: Theory, Methods, Review, International Atomic Energy Agency and United Nations Educational, Scientific and Cultural Organization.

[28] Coplen, T.B., Herczeg, A.L., and Barnes, C., 2000, "Isotope engineering-using stable isotopes of the water molecule to solve practical problems" in Environmental Tracers in Subsurface Hydrology, Springer, Boston, MA, 79-110.

[29] Kumar, P.J.S., and James, E.J., 2016, Identification of hydrogeochemical processes in the Coimbatore district, Tamil Nadu, India, Hydrol. Sci. J., 61 (4), 719-731.

[30] Setiawan, T., Alam, B.Y.C.S.S.S., Haryono, E., and Hendarmawan, 2020, Hydrochemical and environmental isotopes analysis for characterizing a complex karst hydrogeological system of Watuputih area, Rembang, Central Java, Indonesia, Hydrogeol. J., 28 (4), 1635-1659.

[31] Rusydi, A.F., Naily, W., and Lestiana, H., 2015, Domestic and agricultural waste pollution of shallow groundwater in Bandung Regency, JRGP, 25 (2), 87-97.

[32] Kehew, A.E., 2001, Applied Chemical Hydrogeology, Prentice Hall, New Jersey.

[33] Paul, R., Brindha, K., Gowrisankar, G., Tan, M.L., and Singh, M.K., 2019, Identification of hydrogeochemical processes controlling groundwater quality in Tripura, Northeast India using evaluation indices, GIS, and multivariate statistical methods, Environ. Earth Sci., 78 (15), 470.

[34] Singh, A.K., Raj, B., Tiwari, A.K., and Mahato, M.K., 2013, Evaluation of hydrogeochemical processes and groundwater quality in the Jhansi district of Bundelkhand region, India, Environ. Earth Sci., 70 (3), 1225-1247.

[35] Hem, J.D., 1985, Study and interpretation of the chemical characteristics of natural water, Water Supply Paper 2254, U.S. Geological Survey. 